\title{
Ammonia poisoning causes muscular but not liver damage in cattle
}

\author{
[Intoxicação por ammonia causa lesões musculares e não hepáticas em bovinos] \\ A.C. Antonelli ${ }^{1}$, G.A.S. Torres ${ }^{1}$, P.C. Soares ${ }^{2}$, C.S. Mori ${ }^{1}$ \\ M.C.A. Sucupira ${ }^{1}$, E.L. Ortolani ${ }^{1 *}$ \\ ${ }^{1}$ Faculdade de Medicina Veterinária e Zootecnia - USP \\ Av. Prof. Dr. Orlando Marques de Paiva, 87 \\ 05508-900 - São Paulo, SP \\ ${ }^{2}$ Departamento de Medicina Veterinária - UFRPE
}

\begin{abstract}
Twelve steers were intraruminally administered a high dose $(0.5 \mathrm{~g} / \mathrm{kg} \mathrm{BW})$ of urea to study the damage effect of ammonia poisoning on liver and/or muscles. Blood samples were collected to determine ammonia and activities of $\gamma \mathrm{GT}$, AST and CK. Eleven steers were successfully poisoned and treated properly, but one succumbed. Poisoned cattle showed high concentration of ammonia, and higher activities of AST and CK. The higher the ammonia, the greater were the activities of AST $(r=0.59)$ and $\mathrm{CK}(\mathrm{r}=0.61)$. The correlation between AST and CK was high and significant $(\mathrm{r}=0.80)$, but not between AST and $\gamma$ GT $(r=0.19)$. The activities of AST and CK were higher after the beginning of the convulsive episodes due to ammonia poisoning. Those results showed that occurred muscle damage instead of liver damage since CK is a typical enzyme from skeletal muscle; AST is found either in skeletal muscle and hepatocytes, while $\gamma \mathrm{GT}$ is present in hepatic cells.
\end{abstract}

Keywords: cattle, ammonia poisoning, urea, muscle damage, liver

\section{RESUMO}

Doze novilhos foram experimentalmente intoxicados por administração intrarruminal com alta dose de uréia $(0,5 \mathrm{~g} / \mathrm{kg} P V)$ para estudar o efeito da intoxicação por uréia sobre o fígado elou musculatura. Foram coletadas amostras de sangue no decorrer do experimento para determinar o teor de amônia e as atividades de gama glutamiltransferase $(\gamma \mathrm{GT})$, aspartato aminotransferase (AST) e creatina quinase (CK). Onze novilhos apresentaram quadro clínico típico de intoxicação por amônia, porém um animal sucumbiu. Animais intoxicados apresentaram alto teor de amônia e elevada atividade de CK e AST. Quanto mais elevados foram os teores de amônia maiores foram as atividades de AST $(r=0,59)$ e CK $(0,61)$. A correlação entre AST e CK foi alta e significativa $(r=0,80)$, ocorrendo o inverso com AST e $\gamma G T$ $(r=0,19)$. Tanto a atividade de AST como de CK aumentaram significativamente a partir dos episódios convulsivos decorrentes da intoxicação por amônia. Estes resultados indicam que ocorreu uma expressiva lesão muscular, mas não hepática, visto que a CK é uma enzima típica da musculatura estriada; e o AST encontra-se tanto na musculatura estriada como nos hepatócitos, enquanto que a $\gamma \mathrm{GT}$ está presente somente em células hepáticas.

Palavras-chave: bovino, intoxicação por amônia, uréia, lesão muscular, fígado

Recebido para publicação em 21 de outubro de 2004

Aceito em 20 de setembro de 2006

* Autor para correspondência (corresponding author)

E-mail: ortolani@usp.br 


\section{INTRODUCTION}

Cattle raised under extensive management on subtropical or tropical environment need to be supplemented with any source of protein or nitrogen, principally during the dry season, because protein is the main limiting nutrient for ruminants grazing during the dry or winter season. Preformed proteins are expensive and mainly used to human nutrition so the cheapest way to supplement protein to cattle is through the use of nonproteic nitrogen (NPN) (Froslie, 1977). The less expensive and most important source of NNP nowadays is urea, which can replace up to $35 \%$ of ration protein nitrogen for ruminants (Helmer and Bartley, 1971). More than 20 million Brazilian beef and dairy cattle are supplemented with urea yearly (Kitamura et al., 2003).

The rumen microorganisms hydrolyze urea into ammonium $\left(\mathrm{NH}_{4}^{+}\right)$and ammonia $\left(\mathrm{NH}_{3}\right)$ to synthesize their own protein. At a $\mathrm{pH}$ 7.0, approximately $99 \%$ of the compound is ammonium and $1 \%$ is ammonia, but as the $\mathrm{pH}$ becomes more alkaline the ammonia level gets higher (Visek, 1984). Usually, most of the urea is converted in the rumen into ammonium that is available to the rumen microbiota, while the small amount of ammonia produced is absorbed by rumen wall into the blood for the reason that ammonia is lipidsoluble (Bartley et al., 1976; Froslie, 1977). Normally, the liver can detoxify ammonia into urea efficiently synthesizing in the hepatocytes by Krebs \& Henseleit cycle urea, which is 40 times less toxic than ammonia (Visek, 1968). Chalmers et al. (1971) made evident that $100 \mathrm{~g}$ of liver could detoxify $150 \mathrm{mg}$ of ammonia, which is equivalent to $6-7 \mathrm{mg}$ of ammonia per $100 \mathrm{ml}$ of portal blood. But at higher concentrations in the blood, ammonia will overwhelm hepatocytes capacity of detoxification, and will increase its levels in blood, cerebrospinal fluid and other tissues because cells membranes of mammals are highly permeable to ammonia although their cells tolerates moderate levels of ammonia, resulting in ammonia poisoning (Davidovich et al., 1977; Visek, 1984). The primary mechanism of ammonia poisoning is inhibiting the Krebs cycle, which will lower energy production leading to anaerobic glycolysis and systemic metabolic acidosis (Haliburton and Morgan, 1989).
Ammonia poisoning may occur periodically in ruminants that consume large quantities of urea when they are not adapted to it, when feeds are inappropriately mixed with urea, or in a low energy, low protein, and high roughage diets with high urea levels. The onset of clinical picture may start in a matter of minutes to hours after consumption of urea and in most cases it is acute and can cause heavy mortality (Ortolani et al., 2000). Clinical signs most often observed in ammonia poisoning are restlessness, dullness, weakness, muscle tremors profuse salivation, rumen atony, bloat, dyspnea, incoordination, vocalization, lung edema, tonic-clonic convulsion, and finally death by heart failure (Payne, 1989; Radostits et al., 2002; Kitamura et al., 2003).

Although it is recognized that hyperammoniemia causes biochemical disarrange in cellular metabolism and intense cellular damage to the brain and lungs, few studies were carried out regarded to hepatic and muscle tissues, that during the poisoning accumulate large amounts of ammonia (Payne, 1989).

A light injury in the striated muscle causes both cellular enzymes creatine kinase (CK) and aspartate aminotransferase (AST) leak to the serum. Although the serum $\mathrm{CK}$ activity can be very high after a muscular injury its half life is very short approximately 2 to $4 \mathrm{~h}$, conversely the serum AST activity is lower but its half life longer, about $3 \mathrm{~d}$. Thus to monitor any striated muscle injuries it is recommended to analyze serum CK activity complemented with AST (Kaneko et al., 1997). To evaluate liver damage in adult cattle both serum gamma glutamyltransferase $(\gamma \mathrm{GT})$ and AST levels are proposed, while the serum increase of AST can be unspecific the $\gamma \mathrm{GT}$ is primarily seen elevated only in liver diseases (Kaneko et al., 1997).

The objective of this study was to determine if experimental ammonia poisoning causes liver and/or muscle damage in cattle, as seen by the leakage of their cellular enzymes to serum.

\section{MATERIALS AND METHODS}

Twelve yearling crossbred (Holstein-Gir) healthy steers (body weight range $200-250 \mathrm{~kg}$ ), from a single herd located in the city of Aluminio, Sao Paulo State were used in this experiment. They 
were housed indoors in individual tie stalls and provided, for two months before the trial, the following basal diet with $9.6 \%$ of dry matter of crude protein: $30 \%$ commercial concentrate and $70 \%$ coast-cross hay (Cynodon dactylon (L) Pers), and water (ad libitum). This diet did not contain urea or any source of NPN. In order to administer urea, a fistula to the rumen was surgically made, and fitted and capped with a rubber cannula, during the period of adaptation. The steers were restrained of food for 16 hours before the experiment.

Animals received $0.5 \mathrm{~g} / \mathrm{kg} \mathrm{BW}$ of urea and $2.0 \mathrm{~g} / \mathrm{kg}$ BW of cornstarch, separately. Each animal was used only once in the trial. The urea and the cornstarch were administered within the ventral sac of the rumen by a plastic tube through the rubber cannulla, and then the rumen content was stirred by hand to assure the complete and uniform spreading of the urea.

Venous blood samples were drawn from jugular vein to obtain plasma and serum in the following moments: before giving urea, at the occurrence of the $1^{\text {st }}$ clinical sign, muscle tremors, sternal recumbency, and at the $1^{\text {st }}$ convulsive episode for determination of plasma ammonia and the serum activities of AST, $\gamma \mathrm{GT}$ and CK. All samples were analyzed in the multiple clinical chemistry autoanalyzer $^{1}$ using commercial diagnostic kits.

All animals were treated properly when a convulsive episode was first observed or at the end of $240 \mathrm{~min}$. The rumen contents were removed using a siphon, and 101 of isotonic saline solution and 4 litres of rumen content obtained from a healthy steer were administered through the fistula. Animals that exhibited a very severe signs of toxicity such as depressive mental state or the presence of multiple convulsive episodes were treated intravenously with $1 \mathrm{ml} / \mathrm{kg} \quad \mathrm{BW}$ of commercial solution of urea cycle amino acids ${ }^{2}$, $1 \mathrm{mg} / \mathrm{kg} \mathrm{BW}$ furosemide ${ }^{3}$, and $20 \mathrm{ml} / \mathrm{kg} \mathrm{BW}$ isotonic saline solution as recommended by Kitamura et al. (2002).

Descriptive statistics are expressed as means and standard deviation. The data were assessed at first by one-way analysis of variance and the

\footnotetext{
${ }^{1}$ Liasys $^{\circledR}$, AMS, Rome, Italy

${ }^{2}$ Ornitargin ${ }^{\circledR}$ Lab. Baldacci

${ }^{3}$ Zalix ${ }^{\circledR}$ Lab. Intervet
}

means compared by Duncan test. The coefficient of correlation was assessed between all variables, and according to Little and Hills (1978). A high correlation was considered when $r>0.60$; a medium correlation when $0.30<\mathrm{r}<0.60$; and a low correlation when $\mathrm{r}<0.30$, with a $\mathrm{P}<0.0001$ value. Results were considered significant at the $\mathrm{P}<0.05$ value (Sampaio, 1998). The statistical analyses were performed using the MINITAB statistical software (Minitab, 2000).

\section{RESULTS}

At the beginning of the experiments, all steers were healthy, alert and active. The 12 tests resulted in 11 definite toxic cases, with only one steer just exhibiting mild fasciculation and had an uneventful recover. The other 11 steers had typical clinical signs of ammonia poisoning that resulted in convulsive episodes.

The concentration of blood ammonia increased progressively $(\mathrm{P}<0.04)$ (Table 1). The first clinical signs occurred when blood ammonia reached mean values of $782 \mu \mathrm{mol} / 1$. As the clinical picture evolved, when the cattle showed muscle tremors the blood ammonia $\gamma \mathrm{GT}$ concentration rose, reaching an average value of $1136 \mu \mathrm{mol} / 1$, with significant changes when the animals were lying in sternal recumbency, reaching $1272 \mu \mathrm{mol} / 1$. Blood ammonia reached its peak at convulsion, with mean values of $1632 \mu \mathrm{mol} / \mathrm{l}$.

The activity of CK also increased progressively throughout the clinical picture of ammonia poisoning $(\mathrm{P}<0.01)$, but only after the muscle tremors started with $90 \mathrm{U} / 1$. When the steers were lying down in sternal recumbency, the activity of CK were higher than when the muscle tremors started (137U/1), but it reached higher activity levels at convulsion, with 1481U/1.

Values for AST activity remained at physiological ranges (mean 37U/1) until sternal recumbency, but at the beginning of convulsion there was a sudden increased, reaching mean values of $60 \mathrm{U} / 1$ being significant different from the initial values $(\mathrm{P}<0.002)$. No significant differences between the results of $\gamma \mathrm{GT}$ activities throughout the experiment were observed (Table 1). 
Ammonia poisoning causes muscular...

Table 1.Mean values and standard deviation of blood ammonia, and serum activities of CK, AST and $\gamma \mathrm{GT}$ after dosing urea throughout the clinical picture of ammonia poisoning

\begin{tabular}{|c|c|c|c|c|c|c|c|}
\hline & $\mathrm{n}$ & Basal & Onset & Tremors & $\begin{array}{c}\text { Sternal } \\
\text { recumbency }\end{array}$ & Convulsion & $P$ value \\
\hline $\begin{array}{c}\text { Ammonia } \\
(\mu \mathrm{mol} / \mathrm{l})\end{array}$ & 12 & $29 \pm 13 \mathrm{e}$ & $782 \pm 140 \mathrm{~d}$ & $1136 \pm 137 \mathrm{c}$ & $1272 \pm 159 b$ & $1632 \pm 270 \mathrm{a}$ & $<0.04$ \\
\hline $\begin{array}{c}\mathrm{CK} \\
(\mathrm{U} / 1)\end{array}$ & 12 & $68 \pm 20 d$ & $74 \pm 21 \mathrm{~cd}$ & $90 \pm 18 \mathrm{c}$ & $137 \pm 28 b$ & $1481 \pm 606 a$ & $<0.01$ \\
\hline $\begin{array}{l}\text { AST } \\
(\mathrm{U} / 1)\end{array}$ & 12 & $33 \pm 7 b$ & $32 \pm 7 b$ & $34 \pm 7 b$ & $37 \pm 6 b$ & $60 \pm 17 \mathrm{a}$ & $<0.002$ \\
\hline$\gamma \mathrm{GT}(\mathrm{U} / \mathrm{l})$ & 12 & $11.6 \pm 1.7 \mathrm{a}$ & $11.7 \pm 1.7 \mathrm{a}$ & $11.5 \pm 1.8 \mathrm{a}$ & $11.6 \pm 1.8 \mathrm{a}$ & $11.5 \pm 1.8 \mathrm{a}$ & $>0.7$ \\
\hline
\end{tabular}

Different letters in lines indicate significant differences.

There was a significant correlation between blood ammonia and AST (r=0.59) (Fig. 1), and a high correlation between blood ammonia and CK $(\mathrm{r}=0.61) \quad$ (Fig. 2), but an extremely low correlation between blood ammonia and $\gamma \mathrm{GT}$ $(\mathrm{r}=0.01)$. A high correlation between AST and CK (r=0.80) (Fig. 3) was estimated. Conversely, a low non-significant correlation between AST and $\gamma \mathrm{GT}(\mathrm{r}=0.19)$, and CK and $\gamma \mathrm{GT}(\mathrm{r}=0.19)$ was found.

\section{DISCUSSION}

The high correlation between AST and CK but not between AST and $\gamma \mathrm{GT}$ suggested that ammonia poisoning definitely caused muscle but not liver damage. Those lesions might be due to the severity of convulsive episodes and the pathologic recumbency throughout the clinical picture, and so far the higher values for AST and CK activities were detected after the convulsions.

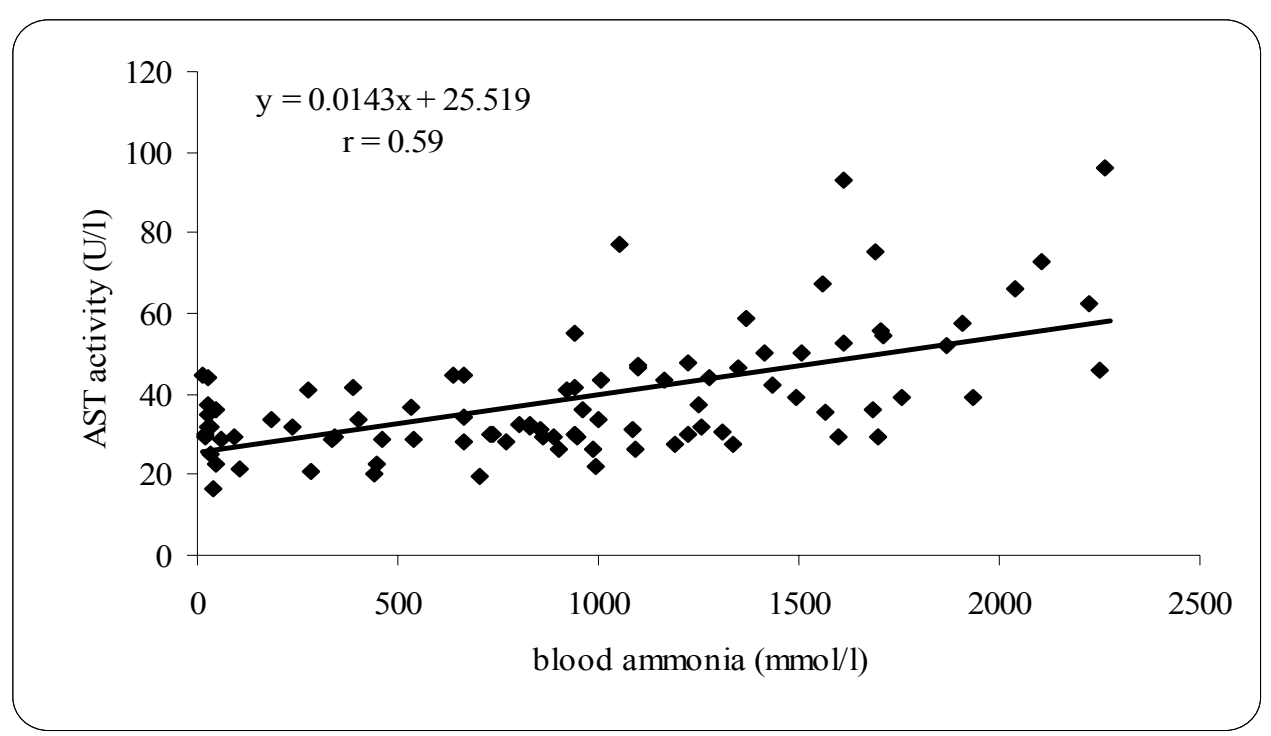

Figure 1. Correlation between blood ammonia and serum AST activity in ammonia-poisoned cattle. 


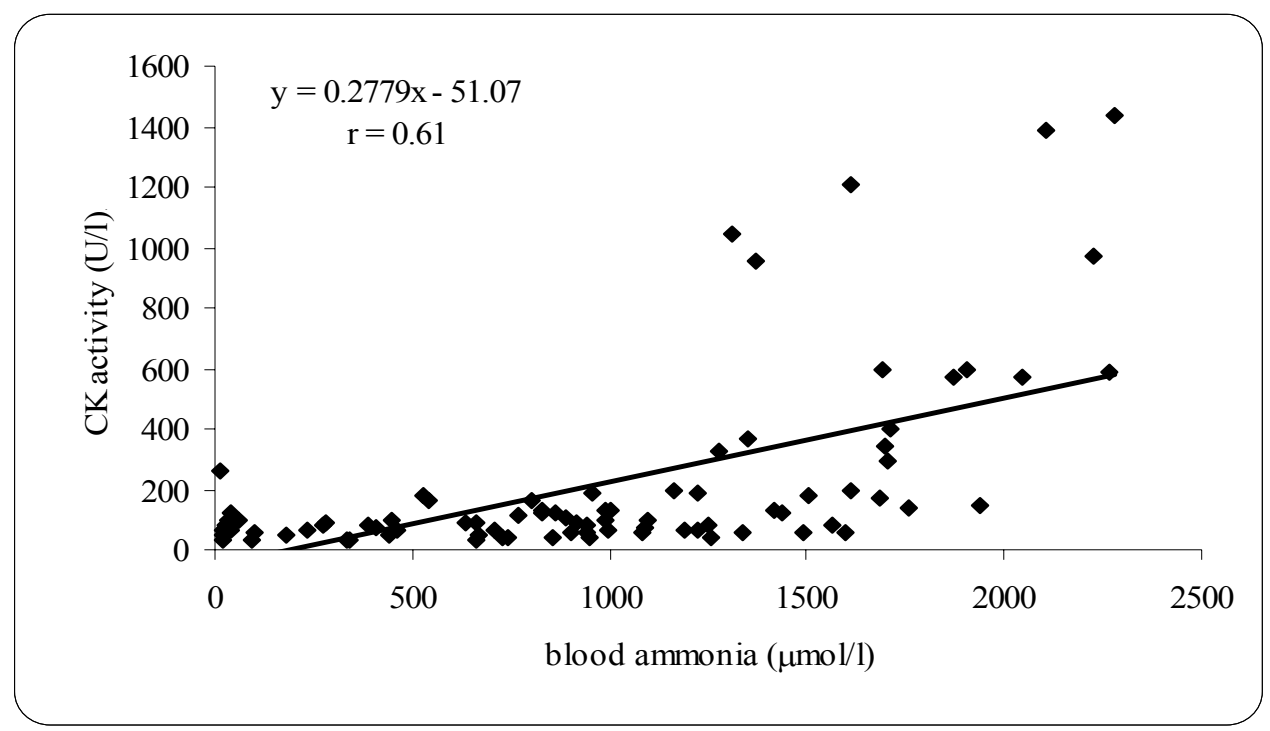

Figure 2. Correlation between blood ammonia and serum CK activity in ammonia-poisoned cattle.

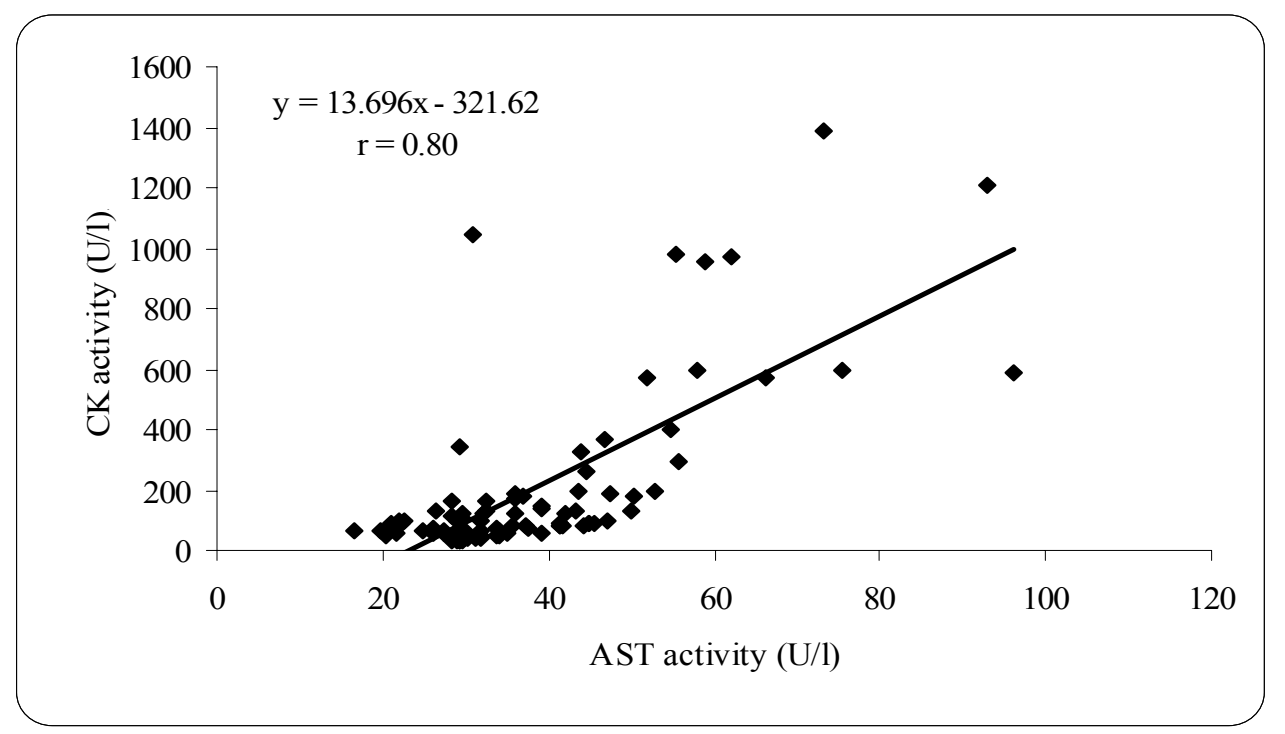

Figure 3. Correlation between serum AST activity and serum CK activity in ammonia-poisoned cattle.

Froslie (1977) reported in his classical review about ammonia poisoning in ruminants that muscle damage may occur sporadically, and no mention was made about liver damage. In a study with sheep, Roller et al. (1982) evaluated the activities of lactate dehydrogenase (LDH), alkaline phosphatase (ALP), AST and CK throughout ammonia poisoning, describing a less intense increase in the first three enzymes and a higher elevation in the activity of CK. The authors mentioned that transaminases would be elevated in hepatic diseases, cardiac necrosis and skeletal muscle damage, leading to an ambiguous conclusion that might exist liver damage. The authors did not emphasized LDH is present in skeletal muscle and ALP in the intestines, and catarrhal enteritis or even a haemorrhagic inflammation in the abomasum and jejunum may occur due to ammonia poisoning (Froslie, 1977).

Singer and McCarty (1971) stated that sheep undergoing ammonia poisoning that died showed massive myocardic and skeletal muscle haemorrhage, and no macroscopic lesion was 
detected in the liver, with only a mild swelling of the hepatocytes. According to Meyer et al. (1995), mild injuries in the hepatocytes almost never cause enzymes releasing in this cells.

The presence of AST in many tissues makes this serum enzyme a nonspecific but sensitive marker of soft tissue damage, but precludes its use as an organ-specific enzyme, and although $\mathrm{CK}$ is a best marker for detect muscle damage, AST is frequently used to complement $\mathrm{CK}$ changes (Kaneko et al., 1997).

The continuous muscle tremors, the pathological recumbency as the several convulsive episodes, typical clinical signs of ammonia poisoning, may represent a strenuous exercise to the animal which could lead to an activity-induced injury of skeletal muscle. This condition often occurs when muscles are active after a period of inactivity or when muscles are exposed to extraordinary conditions. In some situations it results in increased levels of intracellular enzymes such as creatine kinase, with or without structural evidence of muscle damage ( Swenson and Reece, 1993).

\section{REFERENCES}

BARTLEY, E.E.; DAVIDOVICH, A.; BARR, G.W. et al. Ammonia toxicity in cattle. I. Rumen and blood changes associated with toxicity and treatments methods. J. Anim. Sci., v. 43, p.835-841, 1976.

CHALMERS, M.I.; JAFFRAY, A.E.; WHITE, F. Movements of ammonia following intraruminal administration of urea or casein. Proceed. Nutr. Soc., v.30, p.7-17, 1971

DAVIDOVICH, A.; BARTLEY, E.E.; BECHTLE, R. M. et al. Ammonia toxicity in cattle. III. Absorption of ammonia gas from the rumen and passage of urea and ammonia from rumen to the duodenum. J. Anim. Sci., v. 45, p. $551-558,1977$

FROSLIE, A. Feed-related urea poisoning in ruminants. Folia Vet. Lat., v.7, p.17-37, 1977.

HALIBURTON, J. C.; MORGAN, S. E. Nonprotein nitrogen-induced ammonia toxicosis and ammoniated feed toxicity syndrome. Vet. Clin. N. Am.: Food Anim. Pract., v.5, p.237-249, 1989.

HELMER, L.G.; BARTLEY, E.E. Progress in the utilization of urea as a protein replacer for ruminants: a review. J. Dairy Sci., v.54, p.25-51, 1971.
KANEKO, J.J.; HARVEY, J.W.; BRUSS, M.L. Clinical biochemistry of domestic animals. 5.ed. London: Academic, 1997. 932p.

KITAMURA, S.S.; ANTONELLI, A.C.; MARUTA, C.A. et al. A model for ammonia poisoning in cattle. Vet. Hum. Toxicol., v.45, p.274-277, 2003

KITAMURA, S. S.; ORTOLANI, E. L.; ANTONELLI, A. C. Ammonia poisoning in cattle fed dietary urea: basic concepts and new findings. Rev. Educ. Cont. CRMV-SP, v.5, p.292-298, 2002.

LITTLE, T.M.; HILLS, F.J.. Agricultural experimentation: design and analysis. New York: John Wiley, 1978. 350p.

MEYER, D. J.; COLES, E.H.; RICH, L.J. Medicina de laboratório veterinária. São Paulo: Roca, 1995. 320p.

MINITAB. The student edition of MINITAB statistical software adapted for education: 13.0 release user's manual. New York: Wesley, 2000. $624 \mathrm{p}$.

ORTOLANI, E.L.; MORI, C.S.; FILHO, J.A.R.. Ammonia toxicity from urea in a Brazilian dairy goat flock. Vet. Hum. Toxicol., v. 42, p.87-89, 2000.

PAYNE, J.M. Metabolic and nutritional diseases of cattle. Oxford: Blackwell Scientific Publications, 1989. 149 p.

RADOSTITS, O.M.; BLOOD, D.C.; GAY, C.C. Veterinary medicine: a textbook of the diseases of cattle, sheep, pig, goats and horses. London: Baillière Tindall, 1994. 1765p.

ROLLER, M.H.; RIEDEMANN, G.S.; ROMKEMA, G.E. et al. Ovine blood chemistry values measured during ammonia toxicosis. Am. J. Vet. Res., v.43, p.1068-1071, 1982.

SAMPAIO, I.B.M. Estatística aplicada à experimentação animal. Belo Horizonte: Fundação de Ensino e Pesquisa em Medicina Veterinária e Zootecnia, 1998. 221p.

SINGER, R.H.; McCARTY, R.T. Pathologic changes resulting from acute ammonium salt poisoning in sheep. Am. J. Vet. Res., v.32, p.1239-1246, 1971.

SWENSON, M.J.; REECE, W.O. Dukes' physiology of domestic animals. 11.ed. Ithaca: Cornell University, Press, 1993. 962p.

VISEK, W.J. Some aspects of ammonia toxicity in animals cells. J. Dairy Sci., v.51, p.286-295, 1968.

VISEK, W.J. Ammonia: Its effects on biological systems, metabolic hormones, and reproduction. $J$. Dairy Sci., v.67, p.481-498, 1984. 